J. Japan. Soc. Hort. Sci. 50(4) : 481-486. 1982.

\title{
Effects of Nitrogen Supply and Removal of Outer Leaves on the Head Development of Cabbage Plants
}

\author{
Tetsuo Hara, Atsuko Nakagawa, and Yoji Sonoda \\ Faculty of Agriculture, Gifu University, \\ Kakamigahara, Gifu 504
}

\begin{abstract}
Summary
Cabbage (Brassica oleracea L., capitata group) plants were grown in nutrient solutions containing $\mathrm{NO}_{3}-\mathrm{N}$ at 5,50 , and $500 \mathrm{ppm}$. At the beginning of head formation, the outer leaves were removed in various ways, and the effects of the nitrogen supply and the defoliation on the head development were studied.

The head weight increased greatly with an increase of the nitrogen supply from 5 to $50 \mathrm{ppm} \mathrm{N}$ and decreased slightly at $500 \mathrm{ppm} \mathrm{N}$. At 50 or $500 \mathrm{ppm} \mathrm{N}$, the head weight decreased slightly following the removal of the middle and lower outer leaves (i.e. the upper outer leaves were kept intact), while greatly following the removal of the upper and middle outer leaves. At $5 \mathrm{ppm} \mathrm{N}$, the head weight was so small that no clear effect of the defoliation was recognized. The total $\mathrm{N}, 80 \%$ ethanolsoluble $\mathrm{N}$, and $\mathrm{NO}_{3}-\mathrm{N}$ contents in the plants increased with an increase of the nitrogen supply and with the removal of the upper and middle outer leaves. The total sugar content was lower at 5 and $500 \mathrm{ppm} \mathrm{N}$ than at $50 \mathrm{ppm} \mathrm{N}$, and decreased with the removal of the upper and middle outer leaves. The ratio of the total carbohydrate to the total $\mathrm{N}$ contents of the outer leaves was about 10 in the intact (control) plants which were grown at $50 \mathrm{ppm} \mathrm{N}$ and had the largest head weight.
\end{abstract}

\section{Introduction}

Head formation of Chinese cabbage plants is brought about by the incurving development of the inner leaves which are shaded each other. That is, the green outer leaves shade the developing inner leaves, and then the inner leaves incurve and form the head. Hormonal activity in the leaves is the most essential factor responsible for the heading process together with the metabolism of ni trogen and carbohydrates $(4,7)$. External factors, such as light intensity, daylength, temperature, and nutrient supply, also affect strongly the head formation and head quality of cabbage, Chinese cabbage, and lettuce plants $(1,5,6,8)$. However, information on the head formation of cabbage plants is limited, and the necessity of studying the head formation has been emphasized(9).

We have studied the role of macronutrients

Received for publiction August 17, 1981. in the head formation of cabbage plants and clarified that nitrogen is the most influential element among macronutrients(3). For the rapid head development, both nitrogen from the roots and photosynthates from the outer leaves must be supplied adequately for the growth of inner head leaves. If one of the two sources is limited, the head development will not proceed efficiently. From this point of view, the present experiment was conducted to find out how the nitrogen supply combined with partial and complete removal of outer leaves affects the head development.

\section{Materials and Methods}

'Soshu' cabbage seeds (Takii Seeds Co.) were sown on March 17 in vermiculite nursery in a green house, and the seedlings were transplanted on April 15 into 4-liter pots containing a standard nutrient solution. The nutrient solution contained $50 \mathrm{ppm} \mathrm{N}, 20 \mathrm{ppm}$ $\mathrm{P}, \quad 50 \mathrm{ppm} \mathrm{K}, \quad 100 \mathrm{ppm} \mathrm{Ca}, 25 \mathrm{ppm} \mathrm{Mg}$, and adequate amounts of micronutrients(2), and 


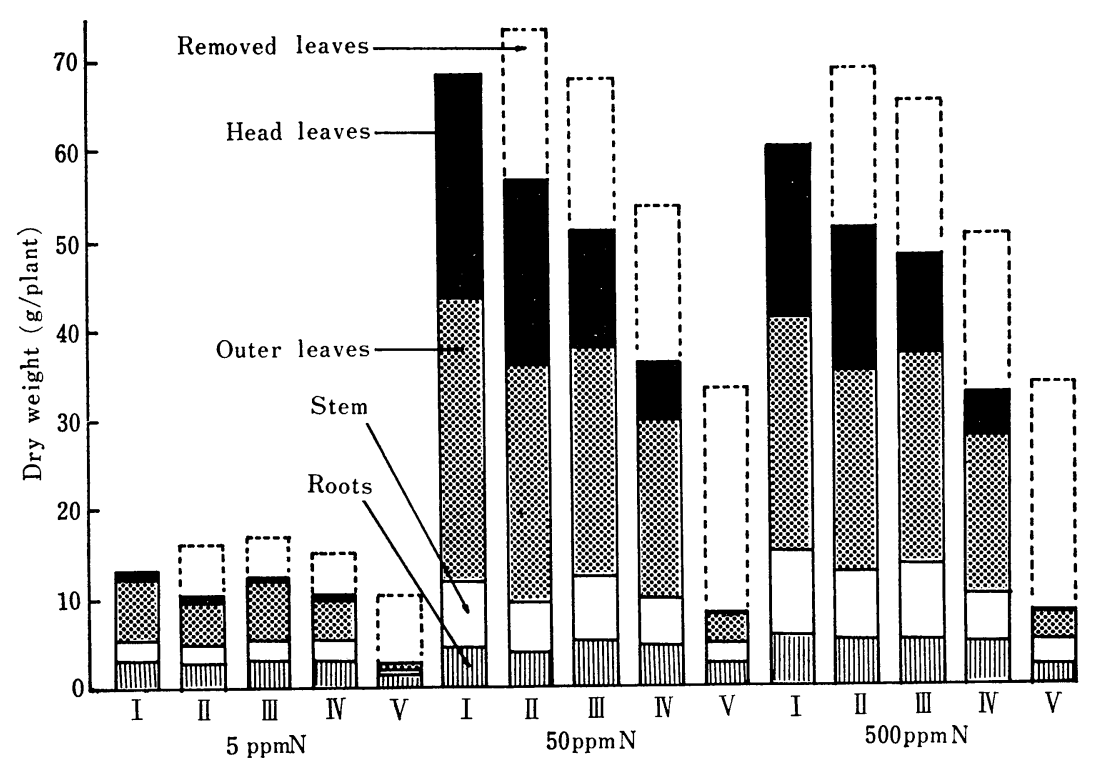

Fig. 1. Effects of nitrogen supply and removal of outer leaves on the dry weight of each organ at harvest. I ; Untreated (control), II ; Middle and lower outer leaves were removed, III ; Upper and lower outer leaves were removed, IV ; Upper and middle outer leaves were removed, V ; All outer leaves were removed.

it was aerated occasionally and renewed once a week. After the plants were recovered from the transplanting damage and started to grow normally, they had the nitrogen treatments from May 2 to harvest. The nitrogen concentration in the nutrient solution was changed to 5,50 , and $500 \mathrm{ppm}$ by use of $\mathrm{NaNO}_{3}$. On May 31, the removal of outer leaves of the plants was done as follows; (I) untreated(control), (II) the 5 middle and 5 lower outer leaves were removed, (III) the 5 upper and 5 lower outer leaves were removed, (IV) the 5 upper and 5 middle outer leaves were removed and, (V) all the outer leaves were removed. The nitrogen treatments and the defoliation treatments were replicated twice. At this growth stage, the head size at $50 \mathrm{ppm} \mathrm{N}$ was about $5 \mathrm{~cm}$ in diameter. As there were 15 outer leaves which were green and active on the stem, 5 leaves each at the upper, the middle, and the lower positions among the outer leaves were kept intact in the defoliation treatements II, III, and IV, respectively. The removed leaves were dried at $70^{\circ} \mathrm{C}$ and weighed. All the plants were harvested simultaneously 103 days after sowing, and the fresh weight of each head and the number of outer leaves were measured. The plants were separated into the head leaves, outer leaves, stem, and roots.

Total $\mathrm{N}$ (excluding $\mathrm{NO}_{3}-\mathrm{N}$ ) and $80 \%$ ethanol-soluble $\mathrm{N}$ in the plant samples were determined by the Kjeldahl method, $\mathrm{NO}_{3}-\mathrm{N}$ by the colorimetric naphthylamine method (12), and total sugar and crude starch by the colorimetric anthrone method(10).

\section{Results}

Plant growth and head weight.

There was a great difference in the dry weight of the plants at harvest(Fig. 1). The dry weight of each organ of the control plants increased greatly with an increase of the nitrogen supply from 5 to $50 \mathrm{ppm} \mathrm{N}$ and decreased slightly at $500 \mathrm{ppm}$ N. Symptoms of nitrogen dificiency were observed in the plants at $5 \mathrm{ppm} \mathrm{N}$. The leaves turned purple and the roots became slim and long. The head weight of the control plants was in the following order in relation to the nitrogen treatments; $50>500 \gg 5 \mathrm{ppm} \mathrm{N}$ (Table 1 ). At 50 or $500 \mathrm{ppm} \mathrm{N}$, both the dry weight of each organ and the head weight decreased 
Table 1. Effects of nitrogen supply and removal of outer leaves on the total number of outer leaves and on the head weight at harvest. The increase in the number of outer leaves from defoliation to harvest is shown in the parentheses.

\begin{tabular}{|c|c|c|c|c|c|}
\hline \multirow{2}{*}{$\begin{array}{c}\mathrm{N} \text { supply } \\
(\mathrm{ppm})\end{array}$} & \multicolumn{5}{|c|}{ Defoliation treatment* } \\
\hline & I & II & III & IV & $\mathrm{V}$ \\
\hline & \multicolumn{5}{|c|}{ Number of outer leaves } \\
\hline 5 & $12(-3)$ & $10(+5)$ & $10(+5)$ & $10(+5)$ & $6(+6)$ \\
\hline 50 & $15(0)$ & $11(+6)$ & $13(+8)$ & $14(+9)$ & $8(+8)$ \\
\hline \multirow[t]{2}{*}{500} & $14(-1)$ & $11(+6)$ & $13(+8)$ & $13(+8)$ & $8(+8)$ \\
\hline & \multicolumn{5}{|c|}{ Head weight ( $g$ fresh weight) } \\
\hline 5 & 7 & 3 & 3 & 3 & 0 \\
\hline 50 & 296 & 244 & 155 & 84 & 5 \\
\hline 500 & 230 & 201 & 137 & 70 & 5 \\
\hline
\end{tabular}

* See Fig. 1.

slightly, greatly and drastically following to the removal of the middle and lower outer leaves, upper and middle outer leaves and all the outer leaves respectively, as compared with control plants. Thus, the head weight at 50 or $500 \mathrm{ppm} \mathrm{N}$ was in the following order in relation to the defoliation treatments; I $>$ II $>$ III $>$ IV $>$ V. At $5 \mathrm{ppm} \mathrm{N}$, the removal of all the outer leaves resulted in a decrease in the dry weight of each organ, but there was not a great difference in dry weight among the partial defoliation treatments. When the weight of the removed leaves was included, the total dry weight in the defoliation treatment II at $50 \mathrm{ppm} \mathrm{N}$ and the defoliation treatments II and III at 500 ppm $\mathrm{N}$ exceeded that of the control plants (Fig. 1).

Following the removal of outer leaves, the head leaves spread out. After the removal of the upper outer leaves, the head leaves expanded outward, thus the number of outer leaves increased from 5 at the start of treatments to $10 \sim 14$ at harvest in the defoliation treatments III and IV and 0 to $6 \sim 8$ in the defoliation treatment $\mathrm{V}$ (Table 1). Number of the head leaves spreading out was less when the upper outer leaves was kept intact (defoliation treatment II), and the increase in the number of outer leaves at harvest was smaller than that of the defoliation treatments $\mathrm{III} \sim \mathrm{V}$.

Nitrogen content in the plants.
The total $\mathrm{N}$ content in the outer leaves increased with an increase of the nitrogen supply(Table 2). At each nitrogen level, the total $\mathrm{N}$ content was highest when all the outer leaves were removed, and was lowest in the control plants. Among the partial defoliation treatments, the total $\mathrm{N}$ content was higher when the lower outer leaves were kept intact than when the upper outer leaves were kept intact. These tendencies were recognized also in the head leaves, except that the total $\mathrm{N}$ content was higher at $5 \mathrm{ppm} \mathrm{N}$ than at $50 \mathrm{ppm} \mathrm{N}$ regardless of the defoliation treatments.

The $80 \%$ ethanol-soluble $\mathrm{N}$ and $\mathrm{NO}_{3}-\mathrm{N}$ contents increased with an increase of the nitrogen supply(Table 3). They also increased remarkably following the removal of all the outer leaves, while slightly following the

Table 2. Effects of nitrogen supply and removal of outer leaves on the total $\mathrm{N}$ content (\% on a dry basis) in the head and outer leaves at harvest.

\begin{tabular}{c|c|c|c|c|c}
\hline \hline \multirow{2}{*}{$\begin{array}{c}\text { N supply } \\
\text { (ppm) }\end{array}$} & \multicolumn{5}{|c}{ Defoliation treatment* } \\
\cline { 2 - 6 } & I & II & III & IV & V \\
\hline & \multicolumn{5}{|c}{ Head leaves } \\
5 & 3.69 & 3.84 & 3.78 & 4.25 & - \\
50 & 2.78 & 3.12 & 3.38 & 3.67 & 4.33 \\
500 & 3.91 & 3.95 & 4.60 & 5.00 & 5.56 \\
& \multicolumn{5}{|c}{ Outer leaves } \\
5 & 1.26 & 1.40 & 1.78 & 1.91 & 3.15 \\
50 & 2.26 & 2.47 & 2.56 & 2.91 & 3.65 \\
500 & 3.51 & 3.46 & 3.61 & 3.96 & 4.49 \\
\hline
\end{tabular}

* See Fig. 1 .

Table 3. Effects of nitrogen supply and removal of outer leaves on the $80 \%$ e thanol-soluble $\mathrm{N}$ and $\mathrm{NO}_{3}-\mathrm{N}$ contents in the outer leaves at harvest.

\begin{tabular}{c|c|c|c|c|c}
\hline \hline \multirow{2}{*}{$\begin{array}{c}\text { N supply } \\
\text { (ppm) }\end{array}$} & \multicolumn{5}{|c}{ Defoliation treatment* } \\
\cline { 2 - 6 } & $\mathrm{I}$ & $\mathrm{II}$ & $\mathrm{III}$ & $\mathrm{N}$ & $\mathrm{V}$ \\
\hline \multicolumn{5}{c}{$80 \%$ ethanol-soluble N (\% on a dry basis) } \\
5 & 0.35 & 0.32 & 0.45 & 0.48 & 1.13 \\
50 & 0.78 & 0.86 & 0.90 & 1.08 & 1.42 \\
500 & 1.47 & 1.45 & 1.55 & 1.78 & 2.47 \\
& \multicolumn{5}{|c|}{$\mathrm{NO}_{3}-\mathrm{N}(\%$ on a dry basis) } \\
4 & 0.03 & 0.03 & 0.05 & 0.07 & 0.17 \\
50 & 0.16 & 0.15 & 0.15 & 0.18 & 0.29 \\
500 & 0.47 & 0.40 & 0.46 & 0.60 & 0.62 \\
\hline
\end{tabular}

* See Fig. 1. 
Table 4. Effects of nitrogen supply and removal of outer leaves on the total sugar content (glucose $\%$ on a dry basis) in the head and outer leaves at harvest.

\begin{tabular}{c|r|r|r|r|r}
\hline \hline \multirow{2}{*}{$\begin{array}{c}\text { N supply } \\
\text { (ppm) }\end{array}$} & \multicolumn{5}{|c}{ Defoliation treatment* } \\
\cline { 2 - 6 } & \multicolumn{1}{|c|}{ I } & II & III & IV & V \\
\hline & \multicolumn{5}{|c}{ Head leaves } \\
5 & 8.2 & 7.3 & 7.0 & 8.0 & - \\
50 & 22.5 & 21.6 & 20.2 & 20.2 & 5.5 \\
500 & 13.7 & 12.5 & 13.0 & 10.4 & 5.8 \\
& \multicolumn{5}{|c|}{ Outer leaves } \\
5 & 9.5 & 8.2 & 7.9 & 8.6 & 0.3 \\
50 & 16.6 & 16.0 & 14.9 & 12.5 & 3.4 \\
500 & 5.3 & 4.8 & 5.3 & 4.7 & 3.1 \\
\hline
\end{tabular}

* See Fig. 1.

partial removal of outer leaves.

Total sugar and crude starch contents in the plants.

The total sugar content at 50 or $500 \mathrm{ppm}$ $\mathrm{N}$ was higher in the head leaves than in the outer leaves(Table 4). As the nitrogen supply increased from 5 to $50 \mathrm{ppm} \mathrm{N}$, the total sugar content in the head and outer leaves increased but it decreased at $500 \mathrm{ppm} \mathrm{N}$. The decrease at the highest nitrogen level was larger in the outer leaves than in the head leaves. At each nitrogen level, the total sugar content was highest in the control plants. It decreased greatly when all the outer leaves were removed, while slightly when the outer leaves were removed partially.

The crude starch content in the head and outer leaves decreased with an increase of the nitrogen supply (Table 5). At 5 or $50 \mathrm{ppm} \mathrm{N}$,

Table 5. Effects of nitrogen supply and removal of outer leaves on the crude starch content (glucose $\%$ on a dry basis) in the head and outer leaves at harvest.

\begin{tabular}{c|r|c|c|c|c}
\hline \multirow{2}{*}{$\begin{array}{c}\text { N supply } \\
(\mathrm{ppm})\end{array}$} & \multicolumn{5}{|c}{ Defoliation treatment* } \\
\cline { 2 - 6 } & $\mathrm{I}$ & II & III & IV & V \\
\hline & \multicolumn{5}{|c}{ Head leaves } \\
5 & 7.5 & 6.4 & 6.4 & 5.3 & - \\
50 & 4.2 & 3.8 & 3.3 & 3.1 & 2.6 \\
500 & 2.8 & 2.5 & 2.8 & 2.5 & 2.6 \\
& \multicolumn{6}{|c|}{ Outer leaves } \\
5 & 10.2 & 7.1 & 5.6 & 4.6 & 3.5 \\
50 & 5.3 & 4.0 & 4.1 & 3.1 & 2.6 \\
500 & 2.8 & 2.7 & 3.0 & 3.6 & 2.7 \\
\hline
\end{tabular}

* See Fig. 1.
Table 6. Effects of nitrogen supply and removal of outer leaves on the ratio of the carbohydrate to the total $\mathrm{N}$ contents of the outer leaves at harvest.

\begin{tabular}{c|r|r|c|c|c}
\hline \hline \multirow{2}{*}{$\begin{array}{c}\text { N supply } \\
\text { (ppm) }\end{array}$} & \multicolumn{5}{|c}{ Defoliation treatment* } \\
\cline { 2 - 6 } & \multicolumn{1}{|c|}{ I } & \multicolumn{1}{|c}{ II } & III & IV & V \\
\hline 5 & 15.6 & 10.9 & 7.6 & 6.9 & 1.2 \\
50 & 9.7 & 8.1 & 7.4 & 5.4 & 1.6 \\
500 & 2.3 & 2.2 & 2.3 & 2.1 & 1.3 \\
\hline
\end{tabular}

See Fig.1.

the crude starch content decreased when the outer leaves were removed partially or completely, but at $500 \mathrm{ppm} \mathrm{N}$ there was no clear tendency.

Carbohydrate/nitrogen ratio of the outer leaves.

From the results above mentioned, the ratio of the total carbohydrate (i.e. total sugar plus crude starch) to the total $\mathrm{N}$ contents of the outer leaves was computed(Table $6)$. The ratio decreased with an increase of the nitrogen supply and with the removal of outer leaves.

\section{Discussion}

The head formation of cabbage plants starts as the nitrogen content decreases and the carbohydrate content increases to a cer tain level with the plant growth(2). Once a head of cabbage plants begins to be formed, the head development depends on the supply of carbohydrates from the outer leaves when no nutrient supply is limited.

When the outer leaves of cabbage plants are removed partially, the head development slows down. The smallest decrease in the head weight in the defoliation treatment II at 50 and $500 \mathrm{ppm} \mathrm{N}$ (Table a) indicates that among the outer leaves, the upper ones contribute most greatly to the head development. The upper outer leaves can produce more photosynthates than the middle and lower ones, because they are younger and more active in photosynthesis. When the upper outer leaves are removed, the production of photosynthates becomes small and the head development does not proceed efficiently. The absorption of nitrogen by the plants is less afferted by the removal of outer 
leaves than the production of photosynthates, and the accumulation of nitrogen occurrs in the defoliation treatments III and IV. The higher values of the contents of soluble $\mathrm{N}$ and $\mathrm{NO}_{3}-\mathrm{N}$ of the outer leaves in these treatments (Table 3) suggest that the protein synthesis is less active in the case of the removal of upper outer leaves than in the removal of lower outer leaves.

There is a report to indicate that the head leaves of cabbage plants expand outward when the outer leaves are removed partially or completely, and that the head must be shaded continuously by the outer leaves to maintain the head formation posture(9). It was also true in the present experiment. The small number of head leaves which expand in the partial defoliation treatment II (Table 1) indicates the effectiveness of the upper outer leaves in the shading of the head and in the maintenance of the head formation posture. Accordingly, the upper outer leaves not only produce more photosynthates but also promote the head development more efficiently than the lower ones.

When nitrogen dificiency becomes a limiting factor for cabbage growth, the outer leaves become small in size and low in photosynthetic activity. The total $\mathrm{N}$ content lower than $2 \%$ in the outer leaves decreases the sugar content of the head and outer leaves(Table 4), and the normal head development is not expected. When an excess amount of nitrogen is supplied to cabbage plants, the sugar content decreases and the head development slows down because excess nitrogen results in a low photosynthetic rate of leaves(11). The removal of upper outer leaves accompanied with the supply of excess nitrogen results in the accumulation of soluble $\mathrm{N}$ (Table 3 ), and the soluble $\mathrm{N}$ content over $1 \%$ seems undesirable for the head development. These results demonstrate that the nitrogen content of cabbage plants and the balance between carbohydrate production and nitrogen uptake are important factors for the head development. Within the limits of this experiment, it is concluded that the head development of cabbage plants proceeds favourably when the ratio of the carbohy- drate to the total $\mathrm{N}$ contents of the outer leaves is kept at about 10 .

\section{Literature Cited}

1. Fujimura, T., T. Mori, T. Kitano, and Y. Aoki. 1960. Studies on fertilization for lettuce. I. Nutrient absorption at stages of growth and effect of nitrogen and potassium levels and their balance on the growth. J. Japan. Soc. Hort. Sci. 29 : 191-196. (In Japanese, with English summary).

2. Hara, T. and Y. Sonoda. 1979. The role of macronutrients in cabbage-head formation (Preliminary report). Growth performance of a cabbage plant, and potassium nutrition in the plant. Soil Sci. Plant Nutr. $25: 103$ 111.

3. Hara, T. and Y. Sonoda. 1981. The role of macronutrients in cabbage-head formation. II. Contribution to cabbage-head formation of calcium, magnesium or sulfur supplied at different growth stages. Soil Sci. Plant Nutr. $27: 45-54$.

4. Iто, Н. and T. КАто. 1957. Studies on the head formation of Chinese cabbage. Histological and physiological studies of head formation. J. Japan. Soc. Hort. Sci. 26 : 154162. (In Japanese, with English summary).

5. Ifama, S., N. Hamashima, and M. Serizawa. 1952. Ecological studies on vegetables at the regions of different altitude. I. Ecological behaviors of cabbage (Brassica oleracea $\mathrm{L}$. var. capitata L.) in summer seasons. J. Japan. Soc. Hort. Sci. $21: 241-250$. (In Japanese, with English summary).

6. Iwama, S. and M. Serizawa. 1953. Ecological studies on vegetables at the regions of different altitudes. IV. Ecological behaviors of spring-sown Chinese cabbages. J. Japan. Soc. Hort. Sci. 22:87-94. (In Japanese, with English summary).

7. КАто, T. 1964. Studies on the head formation of Chinese cabbage (III). Physiological studies on the earliness of head formation. Res. Rep. Kochi Univ. 13 : Natural Sci. II : 205-210. (In Japanese, with English summary).

8. Като, T. 1967. Studies on the head formation of Chinese cabbage (VI). Effects of light intensity and daylength on the development of leafy head. Res. Rep. Kochi Univ. 16 : Natural Sci. II : 139-147. (In Japanese, with English summary).

9. Kato, T. and A. Sooen. 1978. Physiological studies on the head formation in cabbage. I. Effect of defoliation of wrapper leaves on 
the head formation posture. J. Japan. Soc. Hort. Sci. $47: 351-356$. (In Japanese, with English summary).

10. McCready, R. M., J. Guggolz, V. Silviera, and H. S. Owens. 1950. Determination of starch and amylose in vegetables. Anal. Chem. 22 : 1156-1158.

11. TANAKA, A. and T. Hara. 1970. Nutrio-physiological studies on the photosynthetic rate of the leaf. I. Effect of nitrogen status on the photosynthetic rate in the corn plant. J. Sci. Soil Manure, Japan $41: 502-508$. (In Japanese).

12. Wooley, J. T., G. P. Hicks, and R. H. Hageman. 1960. Rapid determination of nitrate and nitrite in plant material. Agric. Food Chem. $8: 481-482$.

\section{窒素供給量と外葉切除処理がキャベッの結球肥大に及ぼす影響}

\section{原徹夫・中川敦子・園田洋次}

(岐阜大学農学部)

摘 要

\author{
早秋カンランを 3 段階の $\mathrm{NO}_{3}-\mathrm{N}$ 濃度 $(5,50,500$

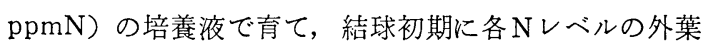 \\ 15 枚のうち上・中・下位各 5 葉のいずれかを残して切 \\ 除し， N供給量と外葉切除処理が結球肥大に及ぼす影響 \\ を調査した。 \\ 結球重は $\mathrm{N}$ 濃度 $5 \mathrm{ppm}$ ではきわめて小さく, $50 \mathrm{ppm}$ \\ で増加し， $500 \mathrm{ppm}$ でやや低下した。N濃度が 50 ある \\ いは $500 \mathrm{ppm}$ の場合には，上・中位葉切除（すなわち \\ 下位葉のみ残した）により結球重は大きく低下したが， \\ 中・下位葉切除では結球重の大きな低下は見られなかっ
}

た. $5 \mathrm{ppm}$ の場合には, 結球重がきわめて小さく, 外葉 切除処理の結球重に対する明瞭な影響は認められなかっ た. 植物体中の全 N， $80 \%$ エタノール可溶性 N および $\mathrm{NO}_{3}-\mathrm{N}$ 含有率は $\mathrm{N}$ 濃度の増加で上昇し，また上・中位 葉切除によりさらに上昇した。全糖含有率は 5 と 500 $\mathrm{ppmN}$ よりも $50 \mathrm{ppmN}$ の場合に高く, 上・中位葉切除 により低下した. $50 \mathrm{ppmN}$ で最高結球重の得られた外 葉無切除植物 (対照区) の場合, 外葉の全炭水化物/全 N含有䍇比は約 10 であった。 